\title{
A Light-Driven Rotaxane Molecular Shuttle with Dual Fluorescence
}

\author{
Addresses
}

\author{
Da-Hui Qu, Qiao-Chun Wang, Jun Ren, He Tian* \\ Lab for Advanced Materials and Institute of Fine Chemicals, East China University of \\ Science \& Technology, Shanghai 200237, P.R. China \\ tianhe@ecust.edu.cn
}

\section{Supporting Information}

\section{Absorption spectra of compound NNCD and NN}
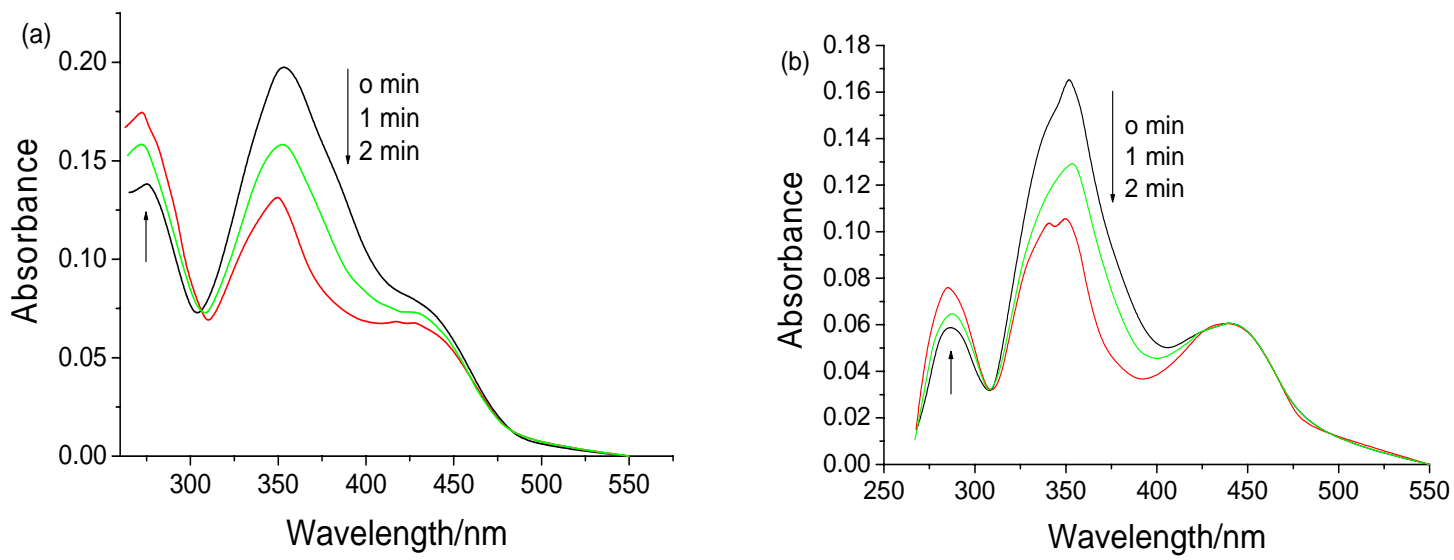

Figure S1. (a) The absorption spectra of [2]rotaxane NNCD in DMF solution $\left(1 \times 10^{-5} \mathrm{M}\right)$ at $25^{\circ} \mathrm{C}$ after irradiation with UV light $360 \mathrm{~nm}$ for $0 \mathrm{~min}, 1 \mathrm{~min}, 2$ min respectively; (b) The absorption spectra of dumbbell NN in DMF solution $\left(1 \times 10^{-5} \mathrm{M}\right)$ at $25^{\circ} \mathrm{C}$ after irradiation with UV light $360 \mathrm{~nm}$ for 0 min, $1 \mathrm{~min}$, 2 min respectively. Both changes are well-regulated.

\section{Experimental section}

\section{General}

H-NMR spectra were measured on a Brüker AM 500 spectrometer. UV/Vis spectra were done on a Varian Cary 500 spectrophotometer (1-cm quartz cell used). Fluorescent spectra were recorded on a Varian Cary Eclipse Fluorescence Spectrophotometer (1-cm quartz cell used). The photoirradiation was carried on a CHF-XM 500-W high-pressure mercury lamp with suitable filters $(360 \mathrm{~nm}, 408 \mathrm{~nm}$ and $430 \mathrm{~nm}$, half

* Corresponding author (E-mail: tianhe@ecust.edu.cn; Fax:+86-21-64252288) 
width $30 \mathrm{~nm}$, type FAL, made in Germany) in a sealed Ar-saturated $1 \mathrm{~cm}$ quartz cell. The distance between the lamp and the sample cell is $20 \mathrm{~cm}$.

\section{Materials}

4-Bromotoulene, 4-nitrosotoulene, 4-iodoaniline and 1,8-naphthalic anhydride were commercially available and used with further purification. $\alpha$-Cyclodextrin, 4-amino- 1,8-naphthalimide, trimethyl boronate were purchased from Acros and used without purification. THF was refluxed over sodium particles and distilled before used. DMF was dried over calcium hydride and distilled under reduced pressure.

\section{Preparation}

The synthetic routes of [2] rotaxane NNCD and NN were shown in Chart S1.

\section{Synthesis of (4-iodo-phenyl)-p-tolyl-diazene (A1):}

4-Nitrosotoulene (2.5 g, $20.7 \mathrm{mmol})$, 4-iodoaniline (4.6 g, $20.6 \mathrm{mmol}$ ) were dissolved in $\mathrm{CH}_{2} \mathrm{Cl}_{2}(20 \mathrm{ml})$ and $\mathrm{CH}_{3} \mathrm{COOH}(30 \mathrm{ml})$. The mixture was stirred for $20 \mathrm{~h}$ under an atmosphere of Ar gas. The precipitate was filtered and washed with ethanol. Recrystalization from ethanol gave pure A1 (6.2 g, 93\%) as red solid. m.p. $155-157^{\circ} \mathrm{C}$. It was pure enough and used directly for the next reaction.

\section{Synthesis of (4-bromomethyl-phenyl)-(4-iodo-phenyl)-diazene (A2):}

A mixture of A1 (5 g, $15.5 \mathrm{mmol})$, NBS (2.9 g, $16.3 \mathrm{mmol}), \mathrm{BPO}\left(0.2 \mathrm{~g}, 0.8 \mathrm{mmol}\right.$ and $\mathrm{CCl}_{4}(80 \mathrm{ml})$ were refluxed for $12 \mathrm{~h}$ under an atmosphere of Ar gas. The resulting solution was filtered while it was hot. The filtrate was cooling down to room temperature to afford red precipitate. The precipitate was filtered and washed with ethanol and dried to give A2 (4.6 g, 75\%). m.p. 198-200 ${ }^{\circ} \mathrm{C} .{ }^{1} \mathrm{H}-\mathrm{NMR}\left(\mathrm{CDCl}_{3}\right): \delta 7.90(\mathrm{~d}$, $2 \mathrm{H}, \mathrm{J}=8.5 \mathrm{~Hz}) ; 7.88(\mathrm{~d}, 2 \mathrm{H}, \mathrm{J}=9.1 \mathrm{~Hz}) ; 7.66(\mathrm{~d}, 2 \mathrm{H}, \mathrm{J}=9.1 \mathrm{~Hz}) ; 7.55$ (d, 2H, J=8.5 Hz); 4.55 (s, 2H).

\section{Synthesis of 6-amino-benzo[de]isoquinoline-1,3-dione-5,8-disulfonic acid disodium salt (A3):}

4-Amino-1,8-naphthalimide (2.0 g, $9.43 \mathrm{mmol})$ was dissolved in oleum $\left(6.5 \mathrm{ml}, 25 \% \mathrm{SO}_{3}\right)$ and the mixture was heated to $100{ }^{\circ} \mathrm{C}$ for $1 \mathrm{~h}$. The mixture was cooled to room temperature and ice water $(50 \mathrm{ml})$ and $\mathrm{NaCl}(15 \mathrm{~g})$ was added with stirring, the precipitate was collected by filtration, washed with water (5 $\mathrm{ml})$ and then acetone $(30 \mathrm{ml})$ and dried to give A3 $(2.9 \mathrm{~g}, 74 \%)$ as yellow solid. m.p. $>300{ }^{\circ} \mathrm{C} .{ }^{1} \mathrm{H}-\mathrm{NMR}$ $\left(\mathrm{D}_{2} \mathrm{O}\right): \delta 8.89(\mathrm{~s}, 1 \mathrm{H}) ; 8.66(\mathrm{~s}, 1 \mathrm{H}) ; 8.59(\mathrm{~s}, 1 \mathrm{H})$.

\section{Synthesis of 6-amino-2-[4-(4-iodo-phenylazo)-benzyl]-benzo[de]isoquinoline-1,3-dione-5,8- disulfonic acid disodium salt (A4):}

To the stirred suspension of A3 $(1.9 \mathrm{~g}, 4.57 \mathrm{mmol})$ in DMF $(15 \mathrm{ml})$ was added dropwise $\mathrm{CH}_{3} \mathrm{ONa}$ solution $\left(0.265 \mathrm{~g}\right.$ in $\left.2.5 \mathrm{ml} \mathrm{CH} \mathrm{CH}_{3} \mathrm{OH}, 4.9 \mathrm{mmol}\right)$ and the resulting mixture was stirred for $3 \mathrm{~h}$ at room temperature, then A2 $(3.8 \mathrm{~g}, 8.42 \mathrm{mmol})$ was added, after stirring for another $4 \mathrm{~h}$, acetone $(80 \mathrm{ml})$ and water $(10 \mathrm{ml})$ was added and the mixture was cooled to $-5{ }^{\circ} \mathrm{C}$, the precipitate was collected by filtration and dried, recrystalized twice from DMF : $\mathrm{H}_{2} \mathrm{O}=1: 4$ to give $\mathrm{A} 4(2.1 \mathrm{~g}, 65 \%)$ as pure yellow solid. m.p. > $300{ }^{\circ} \mathrm{C} .{ }^{1} \mathrm{H}-\mathrm{NMR}\left(\right.$ DMSO-d $\left._{6}\right): \delta 8.96(\mathrm{~s}, 1 \mathrm{H}) ; 8.67(\mathrm{~s}, 1 \mathrm{H}) ; 8.62(\mathrm{~s}, 1 \mathrm{H}) ; 8.20(\mathrm{~s}, 2 \mathrm{H}) ; 7.93(\mathrm{~d}, 2 \mathrm{H}, \mathrm{J}=8.5 \mathrm{~Hz})$; $7.82(\mathrm{~d}, 2 \mathrm{H}, \mathrm{J}=8.5 \mathrm{~Hz}) ; 7.65$ (d, 2H, J=8.5 Hz); 7.51 (d, 2H, J=8.5 Hz); 5.31 (s, 2H).

Synthesis of 4-methylphenylboronic acid (B1): 
The solution of 4-methyltoulene $(12 \mathrm{ml}, 0.1 \mathrm{~mol})$ in dry THF $(100 \mathrm{ml})$ was added into magnesium $(2.52$ $\mathrm{g}, 0.105 \mathrm{~mol})$ in dry THF $(100 \mathrm{ml})$ at the speed of just keeping THF refluxing. After addition finishing, the solution was kept in refluxing for $1 \mathrm{~h}$ with stirring. Lowering the temperature of trimethyl boronate (11.5 $\mathrm{ml}, 0.11 \mathrm{~mol})$ in dry THF $(100 \mathrm{ml})$ to $-10{ }^{\circ} \mathrm{C}$ in ice-salt bath, and the above prepared Gignard reagent was dropwise added into it with stirring. After reacting in $-10{ }^{\circ} \mathrm{C}$ for $1 \mathrm{~h}$, then $10 \%$ sulfuric acid was added to hydrolyze. The THF layer was separated and the aqueous layer was extracted 3 times with ethyl ether. The organic phase was combined and washed with water and dried to give the product in white powder. Recrystalized from $\mathrm{H}_{2} \mathrm{O}$ to give pure $\mathrm{B} 1(8.7 \mathrm{~g}, 65 \%)$. m.p. $256-263^{\circ} \mathrm{C}$.

\section{Synthesis of 4-bromomethylphenylboronic acid (B2):}

A mixture of B1 $(6.2 \mathrm{~g}, 45.9 \mathrm{mmol})$, NBS $(9 \mathrm{~g}, 50.5 \mathrm{mmol}), \mathrm{BPO}(0.5 \mathrm{~g}, 2 \mathrm{mmol})$ and $\mathrm{CCl}_{4}(180 \mathrm{ml})$ were refluxed for $12 \mathrm{~h}$ under an atmosphere of Ar gas. The resulting solution was filtered while it was hot. The filtrate was cooling down to room temperature to afford white precipitate. The precipitate was filtered and washed with $\mathrm{CCl}_{4}$. Recrystalization twice from $\mathrm{CCl}_{4}$ gave pure B2 $(4.6 \mathrm{~g}, 46 \%)$. m.p. $165-172{ }^{\circ} \mathrm{C}$. ${ }^{1} \mathrm{H}-\mathrm{NMR}$ (DMSO-d $\mathrm{d}_{6}$ ): $\delta 8.08$ (s, 2H); 7.75 (d, 2H, J=7.8 Hz); 7.38 (d, 2H, J=7.8 Hz); 4.68 (s, 2H).

\section{Synthesis of benzo[de]isochromene-1,3-dione-5-sulfonic acid sodium salt (B3):}

1,8-Naphthalic anhydride (7.7 g, $39.1 \mathrm{mmol})$ was dissolved in oleum $\left(30 \mathrm{ml}, 25 \% \mathrm{SO}_{3}\right)$ and the mixture was heated to $100^{\circ} \mathrm{C}$ for $1 \mathrm{~h}$. The mixture was cooled to room temperature and ice water $(50 \mathrm{ml})$ and $\mathrm{NaCl}$ $(15 \mathrm{~g})$ was added with stirring, the precipitated product was collected by filtration, washed with water (5 $\mathrm{ml})$ and then ethanol $(30 \mathrm{ml})$ and dried to give B3 $(12 \mathrm{~g}, 94 \%)$ as white solid. m.p. $>300^{\circ} \mathrm{C}$.

\section{Synthesis of benzo[de]isoquinoline-1,3-dione-5-sulfonic acid sodium salt (B4):}

B3 $(4.7 \mathrm{~g}, 5.7 \mathrm{mmol})$ was dissolved in $16 \%$ ammonia solution $(40 \mathrm{ml})$, then the mixture was stirred at $100{ }^{\circ} \mathrm{C}$ for $3 \mathrm{~h}$. After cooling down to room temperature, the deposited white solid was filtered. The solid was stirred in ethanol $(50 \mathrm{ml})$ for $1 \mathrm{~h}$. After being filtered, the filter cake was washed with ethanol and dried to afford a white solid $(4.5 \mathrm{~g}, 96 \%)$. m.p. $>300^{\circ} \mathrm{C}$.

\section{Synthesis of 2-[(4-boronic acid)-yl]-benzyl)-benzo[de]isoquinoline-1,3-dione-5-sulfonic acid sodium salt (B5):}

To the stirred suspension of B4 $(1.0 \mathrm{~g}, 3.34 \mathrm{mmol})$ in DMF $(15 \mathrm{ml})$ was added dropwise $\mathrm{CH}_{3} \mathrm{ONa}$ solution $(0.194 \mathrm{~g}$ in $2.5 \mathrm{ml} \mathrm{CH} 3 \mathrm{OH}, 3.6 \mathrm{mmol})$ and the resulting mixture was stirred for $3 \mathrm{~h}$ at room temperature, then B2 $(0.8 \mathrm{~g}, 3.7 \mathrm{mmol})$ was added, after stirring for another $4 \mathrm{~h}$, acetone $(20 \mathrm{ml})$ and water $(30 \mathrm{ml})$ was added and the mixture was cooled to $-5{ }^{\circ} \mathrm{C}$, the precipitate was collected by filtration and dried, recrystallized twice from DMF : $\mathrm{H}_{2} \mathrm{O}=1: 4$ to give $\mathrm{B} 5(0.5 \mathrm{~g}, 35 \%)$ as pure white solid. m.p. $>300{ }^{\circ} \mathrm{C}$. ${ }^{1} \mathrm{H}-\mathrm{NMR}$ (DMSO-d ${ }_{6}$ ): $\delta 8.68$ (s, 2H); 8.57 (d, 1H, J=8.2 Hz); 8.50 (d, 1H, J=7.2 Hz); 7.96 (s, 2H); 7.88 (dd, $1 \mathrm{H}, \mathrm{J}=7.2 \mathrm{~Hz}, \mathrm{~J}=8.2 \mathrm{~Hz}$ ); 7.70 (d, 2H, J=7.9 Hz); 7.29 (d, 2H, J=7.9 Hz); 5.26 (s, 2H).

\section{Synthesis of [2]rotaxane NNCD}

A4 (0.15 g, $0.2 \mathrm{mmol}), \mathrm{B} 5(0.12 \mathrm{~g}, 0.27 \mathrm{mmol}), \alpha$-cyclodextrin $(0.48 \mathrm{~g}, 0.5 \mathrm{mmol})$, and $\mathrm{Pd}(\mathrm{OAc})_{2}(10$ $\mathrm{mg}, 0.044 \mathrm{mmol})$ were dissolved in Ar-saturated $\mathrm{Na}_{2} \mathrm{CO}_{3}$ aqueous solution $(20 \mathrm{ml}, 0.2 \mathrm{M})$, the mixture was stirred at $85{ }^{\circ} \mathrm{C}$ for $20 \mathrm{~h}$, then cooled and acidified with acetic acid, after concentrated in vacuo, the resulting dark solid was purified by column chromatography (silica gel, the upper layer of 1.3:2:5 acetic acid/n-butanol/water) to give pure NNCD $(0.06 \mathrm{~g}, 15 \%)$ as yellow powder. ${ }^{1} \mathrm{H}-\mathrm{NMR}\left(\mathrm{DMSO}-\mathrm{d}_{6}\right)$ : $\delta 8.96$ (s, 
$1 \mathrm{H}) ; 8.72(\mathrm{~s}, 1 \mathrm{H}) ; 8.70$ (s, 1H); 8.68 (s, 1H); $8.66(\mathrm{~s}, 1 \mathrm{H}) ; 8.58$ (d, 1H, J=8.2 Hz); 8.52 (d, 1H, J=7.3 Hz); 8.17 (d, 2H, J=7.7 Hz); 8.05 (s, 2H); 7.89 (dd, 1H, J=7.3 Hz, J=8.2 Hz); 7.80 (d, 2H, J=7.0 Hz); 7.75 (d, $2 \mathrm{H}, \mathrm{J}=8.6 \mathrm{~Hz}$ ); 7.73 (d, 2H, J=8.6 Hz); 7.50 (d, 2H, J=7.0 Hz); 7.48 (d, 2H, J=7.7 Hz); 5.48 (d, 2H, J=15.3 $\mathrm{Hz}) ; 5.37$ (s, 2H); 5.27 (s, 6H); 5.16 (d, 6H J=7.0 Hz); 4.64 (s, 6H); 4.30 (s, 6H); 3.55 3.50 (m, 24H); 3.24 (m, 6H); 3.1 (s, 6H). ${ }^{1} \mathrm{H}-\mathrm{NMR}\left(\mathrm{D}_{2} \mathrm{O}\right): \delta 8.80(\mathrm{~s}, 1 \mathrm{H}) ; 8.65(\mathrm{~s}, 1 \mathrm{H}) ; 8.58(\mathrm{~s}, 1 \mathrm{H}) ; 8.47(\mathrm{~s}, 1 \mathrm{H}) ; 8.36(\mathrm{~s}, 1 \mathrm{H})$; 8.06 (d, 2H, J=7.9 Hz); 7.92 (dd, 1H, J=7.9 Hz, J=7.6 Hz); 7.8 (d, 3H , J=7.6 Hz); 7.71 (d, 5H, J=7.6 Hz); 7.55 (d, 2H, J=5.7 Hz); 7.32 (d, 2H, J=5.7 Hz); 5.42 (m, 2H); 5.22 (s,2H); 4.80 (d, 6H, J=3.1 Hz); 3.63 (m, $12 \mathrm{H}) ; 3.54(\mathrm{t}, 6 \mathrm{H}, \mathrm{J}=9.2 \mathrm{~Hz}) ; 3.46(\mathrm{~m}, 12 \mathrm{H}) ; 3.35\left(\mathrm{dd}, 6 \mathrm{H}, \mathrm{J}_{1}=3.1 \mathrm{~Hz}, \mathrm{~J}_{2}=9.2 \mathrm{~Hz}\right)$. Elemental analysis calcd (\%) for $\mathrm{C}_{80} \mathrm{H}_{86} \mathrm{~N}_{5} \mathrm{Na}_{3} \mathrm{O}_{43} \mathrm{~S}_{3} \cdot 12 \mathrm{H}_{2} \mathrm{O}$ : C 43.94, H 5.07, N 3.20. Found: C 43.97, H 5.09, N 3.18\%.

\section{Synthesis of NN}

A4 $(0.15 \mathrm{~g}, 0.2 \mathrm{mmol}), \mathrm{B} 5(0.12 \mathrm{~g}, 0.27 \mathrm{mmol})$ and $\mathrm{Pd}(\mathrm{OAc})_{2}(10 \mathrm{mg}, 0.044 \mathrm{mmol})$ were dissolved in Ar-saturated $\mathrm{Na}_{2} \mathrm{CO}_{3}$ aqueous solution $\left(20 \mathrm{ml}, 0.2 \mathrm{M}\right.$ ), the mixture was stirred at $85{ }^{\circ} \mathrm{C}$ for $20 \mathrm{~h}$, then cooled and acidified with acetic acid, after concentrated in vacuo, the resulting dark solid was purified by column chromatography (silica gel, the upper layer of 1:3:5 acetic acid/n-butanol/water) to give pure NN $(0.12 \mathrm{~g}, 30 \%)$ as yellow powder. m.p. $>300{ }^{\circ} \mathrm{C} .{ }^{1} \mathrm{H}-\mathrm{NMR}\left(\mathrm{DMSO}_{\mathrm{d}}\right): 88.95(\mathrm{~s}, 1 \mathrm{H}) ; 8.70(\mathrm{~s}, 1 \mathrm{H}) ; 8.67$ (s, $1 \mathrm{H}) ; 8.66(\mathrm{~s}, 1 \mathrm{H}) ; 8.62(\mathrm{~s}, 1 \mathrm{H}) ; 8.57(\mathrm{~d}, 1 \mathrm{H}, \mathrm{J}=8.0 \mathrm{~Hz}) ; 8.51$ (d, 1H, J=7.2 Hz); 8.00 (s, 2H); 7.93 (d, 2H, $\mathrm{J}=8.2 \mathrm{~Hz}) ; 7.88(\mathrm{dd}, 1 \mathrm{H}, \mathrm{J}=7.2 \mathrm{~Hz}, \mathrm{~J}=8.0 \mathrm{~Hz}) ; 7.82(\mathrm{~d}, 4 \mathrm{H}, \mathrm{J}=8.2 \mathrm{~Hz}) ; 7.69$ (d, 2H, J=8.2 Hz); 7.51 (d, 2H, $\mathrm{J}=8.6 \mathrm{~Hz}) ; 7.48(\mathrm{~d}, 2 \mathrm{H}, \mathrm{J}=8.6 \mathrm{~Hz}) ; 5.31(\mathrm{~s}, 4 \mathrm{H})$. Elemental analysis calcd $(\%)$ for $\mathrm{C}_{44} \mathrm{H}_{26} \mathrm{~N}_{5} \mathrm{Na}_{3} \mathrm{O}_{13} \mathrm{~S}_{3}: \mathrm{C}$ 52.96, H 2.63, N 7.02. Found: C 52.94, H 2.61, N 7.04\%.

Table S1. The relative fluorescence quantum yields (compared with A4 at $\lambda=520 \mathrm{~nm}$ and $\mathbf{B} 4$ at of $\lambda=395$ $\mathrm{nm}$, respectively) of compound NNCD and NN in DMF before and after UV $360 \mathrm{~nm}$ light irradiation.

\begin{tabular}{|c|c|c|c|c|}
\hline \multirow[t]{2}{*}{ compound } & \multicolumn{2}{|c|}{ before irradiation $(\mathrm{E})$} & \multicolumn{2}{|c|}{ after irradiation $(Z)$} \\
\hline & $\Phi_{\mathrm{f}(\lambda=520)}$ & $\Phi_{\mathrm{f}(\lambda=395)}$ & $\Phi_{f(\lambda=520)}$ & $\Phi_{\mathrm{f}(\lambda=395)}$ \\
\hline NNCD & 1.56 & 0.63 & 1.02 & 1.12 \\
\hline $\mathbf{N N}$ & 1.09 & 0.71 & 1.12 & 0.96 \\
\hline
\end{tabular}




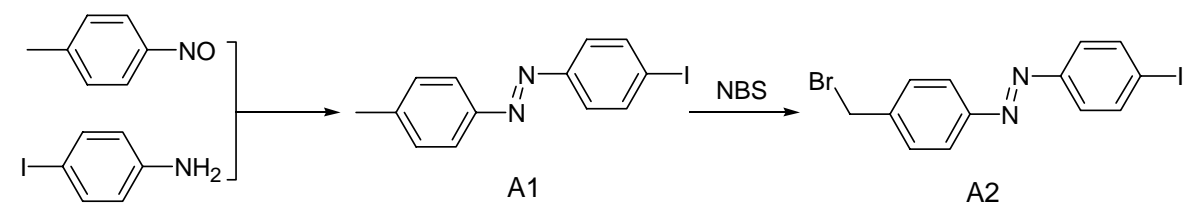

$\underset{\mathrm{B} 1}{\longrightarrow} \mathrm{Br} \frac{\mathrm{Mg}}{\mathrm{B}\left(\mathrm{OCH}_{3}\right)_{3}} \longrightarrow-\mathrm{B}(\mathrm{OH})_{2} \stackrel{\mathrm{NBS}}{\longrightarrow}$
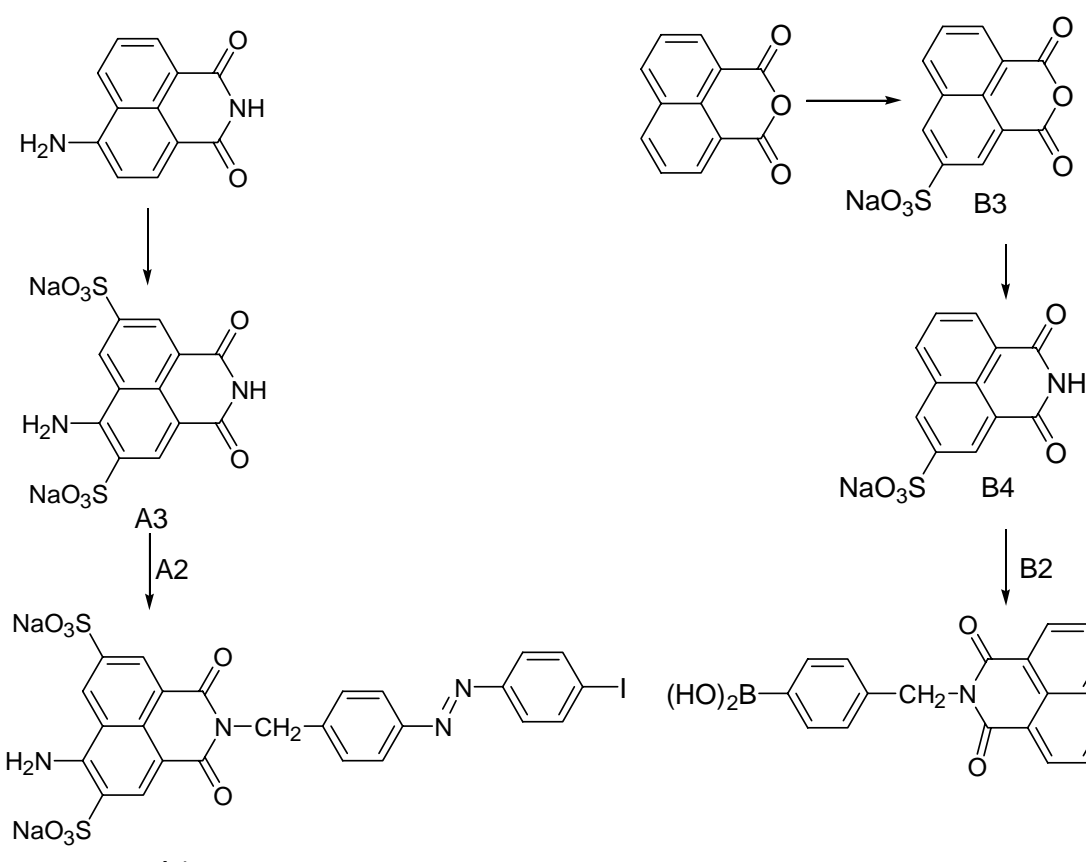

A4
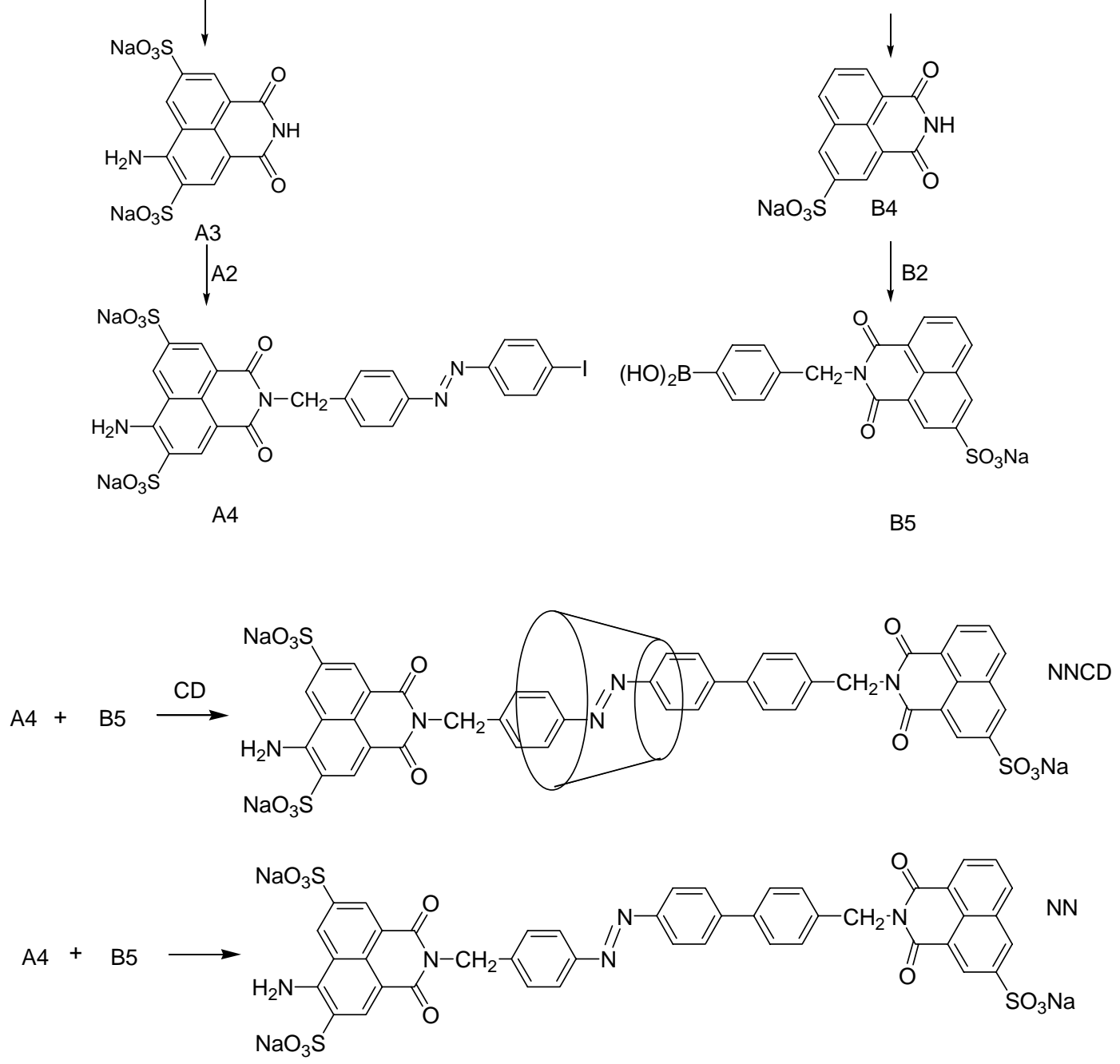

Chart S1. The synthetic routes of compounds NN and NNCD 